\title{
Basement Membrane-Specific Heparan Sulfate Proteoglycan Core Protein
}

National Cancer Institute

\section{Source}

National Cancer Institute. Basement Membrane-Specific Heparan Sulfate Proteoglycan

Core Protein. NCI Thesaurus. Code C95448.

Basement membrane-specific heparan sulfate proteoglycan core protein (4391 aa, 469 $\mathrm{kDa}$ ) is encoded by the human HSPG2 gene. This protein is involved in both the mediation of cell adhesion and the structural integrity of the basement membrane. 